\title{
Continuous Fixed-Bed Column Study and Adsorption Modeling: Removal of Arsenate and Arsenite in Aqueous Solution by Organic Modified Spent Grains
}

\author{
Chen Yunnen*, Wu Ye, Liu Chen, Guo Lin, Nie Jinxia, Ren Rushan \\ Jiangxi Key Laboratory of Mining and Metallurgy Environmental Pollution Control, \\ Jiangxi University of Science and Technology, \\ Kejia Ave. 156, Ganzhou Jiangxi, 341000, P.R. China
}

Received: 28 November 2016

Accepted: 8 February 2017

\begin{abstract}
The adsorption of arsenate $(\mathrm{As}(\mathrm{V}))$ and arsenite $(\mathrm{As}(\mathrm{III}))$ was conducted in a continuous fixed-bed column by using organic modified spent grains (OSGs). The column performances were evaluated by varying the influent flow rate $(0.91,1.36$, and $2.72 \mathrm{ml} / \mathrm{min})$ and arsenic ions initial concentration $(1.0,2.0$, and $6.0 \mathrm{mg} / \mathrm{l}$ for $\mathrm{As}(\mathrm{V}) ; 0.5,1.0$, and $3.0 \mathrm{mg} / \mathrm{l}$ for $\mathrm{As}(\mathrm{III}))$ in order to obtain experimental breakthrough curves. The maximum adsorption capacity was at $6.0 \mathrm{mg} / \mathrm{l}$ for $\mathrm{As}(\mathrm{V})$ and $3.0 \mathrm{mg} / \mathrm{l}$ for $\mathrm{As}(\mathrm{III})$ influent concentration and $1.36 \mathrm{ml} / \mathrm{min}$ flow rate. The Thomas model, Adams-Bohart model, and Yoon-Nelson kinetic models were used to analyze column performance. The value of rate constant for Thomas and Adams-Bohart models decreased with increase of influent concentration, but increased with increasing flow rate. The rate constant for the Yoon-Nelson model decreased with increases in both initial influent arsenic ions concentration and flow rate.
\end{abstract}

Keywords: arsenic removal, adsorption, fixed-bed column, organic modified spent grains (osgs), dynamic modeling

\section{Introduction}

Arsenic is of environmental concern because of its toxicity to plants, animals, and humans. Arsenic in drinking water has the greatest impact on the general population and human health. In natural waters arsenic can be found in inorganic forms as oxidized pentavalent arsenate $(\mathrm{As}(\mathrm{V}))$ or trivalent arsenite $(\mathrm{As}(\mathrm{III}))$, mostly

*e-mail: cyn70yellow@gmail.com as $\mathrm{H}_{2} \mathrm{AsO}_{4}^{-}, \mathrm{HAsO}_{4}^{2-}, \mathrm{H}_{3} \mathrm{AsO}_{3}$, and $\mathrm{H}_{2} \mathrm{AsO}_{3}^{-}[1] . \mathrm{As}(\mathrm{V})$ predominates in surface waters, while groundwater may also contain relevant concentrations of As(III) that are more mobile and toxic than As(V) [2]. Elevated concentrations of arsenic in groundwaters of China are the result of biogeochemical processes [3] or anthropogenic activities such as agriculture (the extensive use of herbicides and insecticides) and irregular disposal of hazardous waste from heavy industry [4-5].

Long-term exposure through drinking water to even low concentrations of arsenic $(\leq 50 \mu \mathrm{g} / \mathrm{l})$ can cause 
carcinogenic diseases of skin, lungs, blood, and kidneys, as well as hyperkeratosis and hyper pigmentation of skin [6-8]. The World Health Organization set a maximum permissible concentration for arsenic in drinking water at $10 \mu \mathrm{g} / \mathrm{L}$ in 1993 [9]. The P. R. of China Department of Health lowered the provisional guideline value in drinking water from $50 \mu \mathrm{g} / \mathrm{l}$ As to $10 \mu \mathrm{g} / \mathrm{l}$ As in July 2006 [10].

There are several technologies for arsenic removal from water and their efficiency depends on the valence of arsenic. Arsenic is most effectively removed or stabilized when it is present in the pentavalent arsenate form. Most of the technologies include ion exchange, precipitation, coagulation and filtration, and oxidation/filtration [1114]. However, they suffer from high cost, low efficiency, incomplete metal removal, high reagent and energy requirements, and the generation of secondary pollution [15]. Adsorption technology still remains attractive and represents an innovative and economical approach to arsenic removal [16-18].

With the development of industry and agriculture, abundant biomass can be seen from the waste of largescale industrial processes and agricultural waste materials [19-20]. At present, one of the largest sources of biomass from industrial waste is spent grains (SGs), which are generated in the brewing process. These are produced in large quantities during brewery production and are far in excess of any local uses (such as animal feed) due to the absence of activity, thus frequently causing disposal problems. Since the chemical pre-treatments can potentially modify the cell surface either by removing the groups or exposing more metal ion binding sites, the physical and chemical properties of SGs can be improved through modification before use as a sorbent of cadmium, lead, and arsenic from aqueous solutions [21-23]. As in our previous paper [24], modified spent grains (SGs) with inorganic substance calcium hydroxide $\left(\mathrm{Ca}(\mathrm{OH})_{2}\right)$ saturated solution can introduce the hydroxyl group, which could have a greater effect on the physical and chemical properties of the surface of spent grains.

The purpose of this study is to investigate the removal performance and adsorption capacity toward arsenic ions from water in the organic modified spent grains (OSGs) fixed-bed column. The dynamic behavior of a fixed-bed column filled with OSGs is described in terms of a breakthrough curve. The effect of important design parameters (containing initial arsenic concentration and flow rate) was investigated. The breakthrough curves for the adsorption of both $\mathrm{As}(\mathrm{V})$ and $\mathrm{As}(\mathrm{III})$ were analyzed using Thomas, Adams-Bohart, and Yoon-Nelson models.

\section{Experimental Material and Methods}

\section{Preparation of Adsorbate}

Stock solutions $(100 \mathrm{mg} / \mathrm{l} \mathrm{As})$ are prepared from dodecahydrate sodium arsenate $\left(\mathrm{Na}_{3} \mathrm{AsO}_{4} \cdot 12 \mathrm{H}_{2} \mathrm{O}\right.$; $>99.0 \%)$ for $\mathrm{As}(\mathrm{V})$ and sodium arsenite $\left(\mathrm{NaAsO}_{2} ;>99.0 \%\right)$ for $\mathrm{As}(\mathrm{III})$. The volumetric flask is stored in a refrigerator.
$\mathrm{As}(\mathrm{V})$ and $\mathrm{As}(\mathrm{III})$ solutions of different concentrations are obtained by diluting the stock solution with distilled water. All reagents used in this study are analytical grade.

\section{Preparation of OSGs}

The fresh spent grains (SG) sample was obtained from a local brewery located in Ganzhou, P. R. China. The spent grains were washed by distilled water and dried at $60^{\circ} \mathrm{C}$, ground to pass through a 1-mm sieve, and stored dry until use.

SGs were pretreated by a $2 \mathrm{~mol} / \mathrm{L} \mathrm{NaOH}$ solution with solid-liquid ratio of $1 \mathrm{~g} / 10 \mathrm{~mL} 2 \mathrm{~h}$ at room temperature, which was followed by stirring with epichlorohydrin, $\mathrm{NaOH}$, and ethanol with a ratio of $1 \mathrm{~g} / 5 \mathrm{ml} / 8 \mathrm{ml} / 2 \mathrm{ml} 4 \mathrm{~h}$ at $65^{\circ} \mathrm{C}$. After that, the $30 \%$ trimethylamine solution was added with ratio of $1 \mathrm{~g} / 5 \mathrm{~mL}$ to stir $2 \mathrm{~h}$ at $65^{\circ} \mathrm{C}$. Finally, the organic substance modified spent grains were rinsed with copious deionized water to neutralize and dry them at $80^{\circ} \mathrm{C}$, which made them OSGs.

\section{Characterization}

Scanning electron microscopy (SEM) was used to characterize the morphologies of the samples. The FT-IR analysis was conducted by Nicolet 380 FT-IR.

\section{Adsorption Experiments in Fixed-Bed Column}

A glass column $(50 \mathrm{~cm}$ in length and $2.5 \mathrm{~cm}$ in diameter) equipped with a constant-flow variable speed peristaltic pump (Longer-BT100) packed with glass wool as supporting layers at both ends was employed for the fixed-bed column experiments at room temperature. $353 \mathrm{~g}$ of OSG adsorbent was packed into the column to produce a $32 \mathrm{~cm}$ bed height (the process flow diagram is shown in Fig. 1). Before the experiment started, the adsorbent

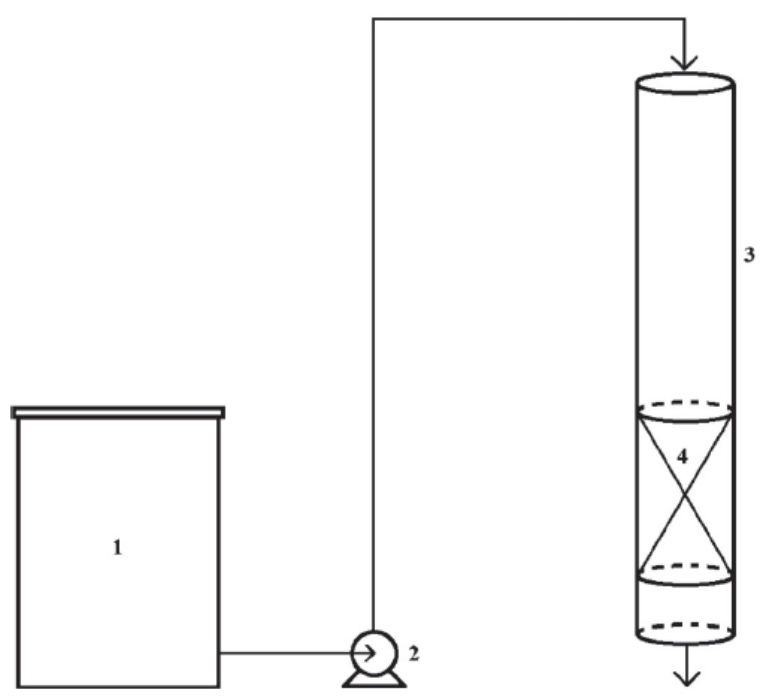

Fig. 1. Schematic diagram of experimental setup. (1) Feed storage, (2) pump, (3) glass column, (4) fixed-bed. 
packed in the column was wetted with deionized water in a downward flow direction to withdraw the trapped air between the particles. Liquid samples of the arsenic in the exit of the fixed-bed experiments were collected at predefined time intervals. The effects of initial arsenic concentration (1.0, 2.0, and $6.0 \mathrm{mg} / \mathrm{L}$ for $\mathrm{As}(\mathrm{V}), 0.5,1.0$, and $3.0 \mathrm{mg} / \mathrm{l}$ for $\mathrm{As}(\mathrm{III}))$ and flow rates $(0.91,1.36$, and $2.72 \mathrm{ml} / \mathrm{min}$ ) on breakthrough time and uptake capacity were investigated. The column operation was halted when the concentration of arsenic in the effluent attained 100\% of influent concentration.

\section{Analysis and Calculations}

$\mathrm{pH}$ adjustments were carried out using $0.1 \mathrm{M}$ $\mathrm{NaOH}$ and/or $0.1 \mathrm{M} \mathrm{HCl}$ solutions. The $\mathrm{pH}$ of the solution is measured using a multi 340i (WTW) digital microprocessor-based $\mathrm{pH}$ meter previously calibrated with standard buffer solutions. The concentrations of arsenic were determined by using an inductively coupled plasma-atomic emission spectrometer (Intrepid II XSP).

Because of the high toxicity of arsenic, the breakthrough point is intended to be $10 \%$ to illustrate the adsorption capacity and breakthrough time for different initial concentrations of arsenic ions and flow rate. Breakthrough time $\left(t_{b}\right)$ is defined as the time to reach a specific breakthrough concentration $C_{b}(10 \%$ of the initial concentration $\left(C_{0}\right)$ ). Column performance is evaluated by plotting the relative concentration of arsenic ions, which is defined as the ratio of the concentration of arsenic ions in effluent to the concentration in influent $\left(C_{t} / C_{0}\right)$ with respect to flow time, $t$.

The adsorption capacity of the fixed-bed column experiment is calculated as follows:

$$
q(10 \%)=\frac{t_{b} \times v \times C_{0}}{M} \times 90 \%
$$

... where $q(10 \%)$ is the breakthrough capacity of adsorbent $(\mathrm{mg} / \mathrm{g})$ when the concentration of solution reach $C_{b}, v$ is the flow rate $(\mathrm{ml} / \mathrm{min})$, and $\mathrm{M}$ is adsorption mass packed in the column $(\mathrm{g})$.

\section{Results and Discussion}

\section{Characterization of SGs and OSGs}

Fig. 2 shows the morphologies of SGs and OSGs. Compared with SGs as shown in Fig. 2a), great changes have taken place in the surface of OSGs (Fig. 2b), which having many folds, parallel grooves, and uniform distribution. We also noticed the appearance of large and small holes on the surface of the OSGs, which may be due to erosion of organic modifier to amplify the specific surface area and activity and to provide more adsorption sites. a)

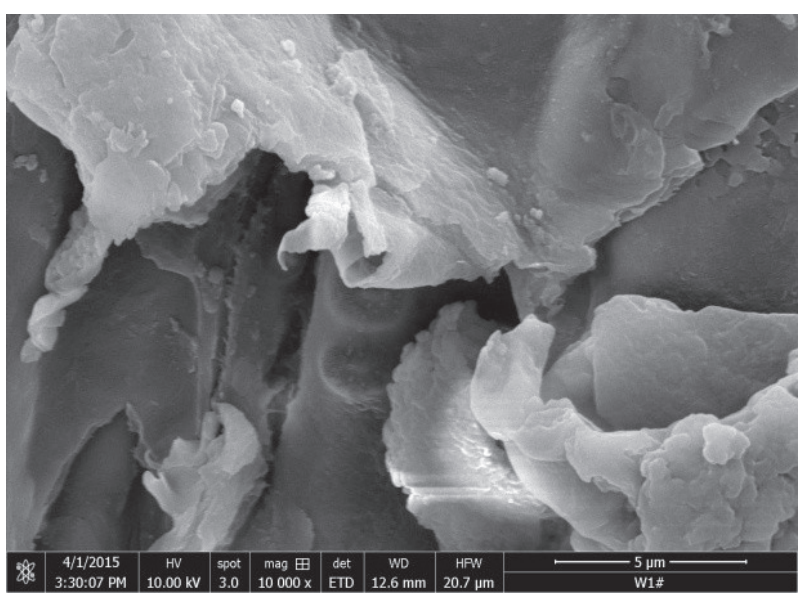

b)

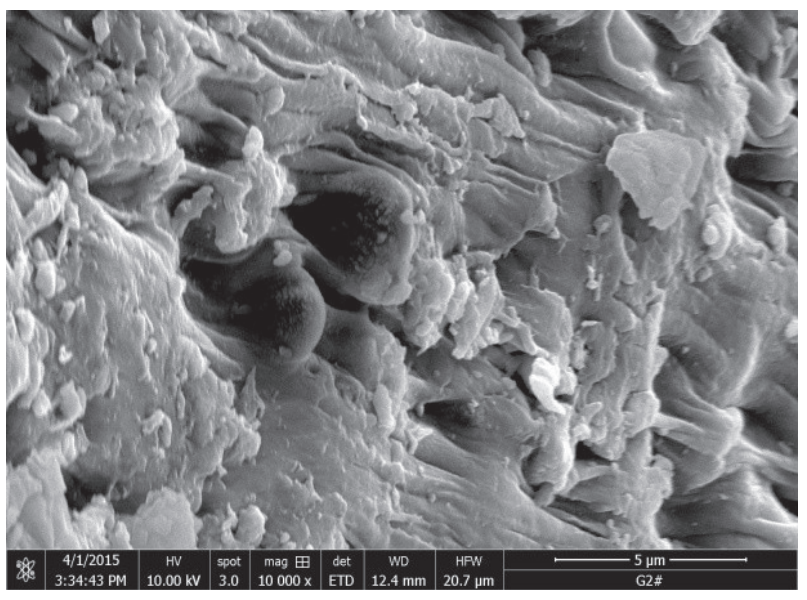

Fig. 2. SEM images of SGs a) and OSGs b).

The FT-IR spectra of SGs and OSGs are shown in Fig. 3. For the SGs, the broad band at $3,276 \mathrm{~cm}^{-1}$ was attributed to hydroxyl groups [25], which shifted to $3,340 \mathrm{~cm}^{-1}$ for the OSGs. It is worth noting that the band at $1,413 \mathrm{~cm}^{-1}$ belonged to $\mathrm{C}-\mathrm{N}$ appeared for OSGs other than SGs, indicating the introduction of quaternary amine groups.

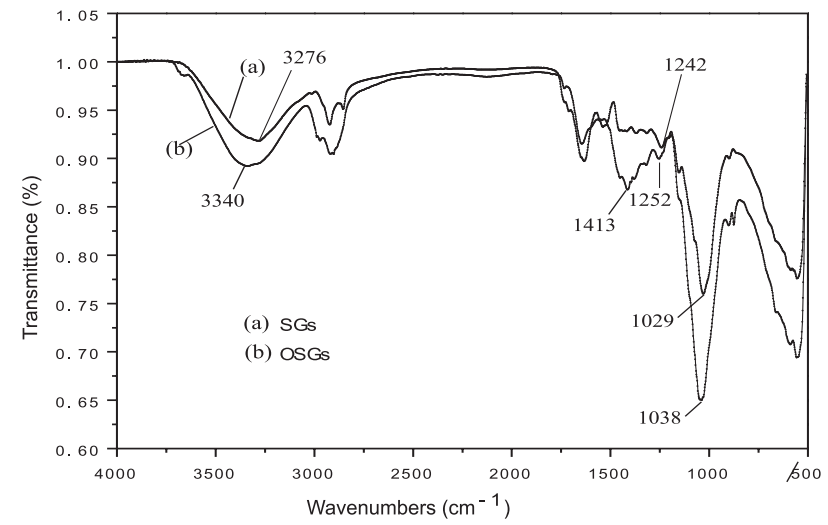

Fig. 3. Fourier transform infrared spectra of SGs and OSGs. 


\section{Effect of Initial Arsenic Concentration}

The column performance of OSGs was conducted at various initial arsenic concentrations when other experimental conditions were kept constant (Fig. 4). The breakthrough time appears to decrease when the initial $\mathrm{As}(\mathrm{V})$ concentration increased from 1.0 to $6.0 \mathrm{mg} / \mathrm{l}$ or As(III) from 0.5 to $3.0 \mathrm{mg} / \mathrm{l}$. But the breakthrough adsorption capacity increased from 0.50 to $0.66 \mathrm{mg} / \mathrm{g}$ for $\mathrm{As}(\mathrm{V})$ and from 0.25 to $0.27 \mathrm{mg} / \mathrm{g}$ for $\mathrm{As}(\mathrm{III})$ with an increase in initial concentration, which may be due to the availability of a greater number of arsenic ions in solution. Moreover, higher initial adsorbate concentration provided a higher driving force to overcome all mass transfer resistances of the metal ions from the aqueous to the solid phase, resulting in higher probability of collision between arsenic ions and the active sites of OSGs. This may be attributed to high influent concentration providing higher driving force for the transfer process to overcome arsenic ions mass transfer resistance [26]. At higher As(V) or As(III) concentrations, the breakthrough curves are sharper due to a relatively smaller mass transfer zone and a more intra-particle diffusion-controlled process. The concentration gradient between the arsenic adsorbed on OSG adsorbent and in the solution could be improved
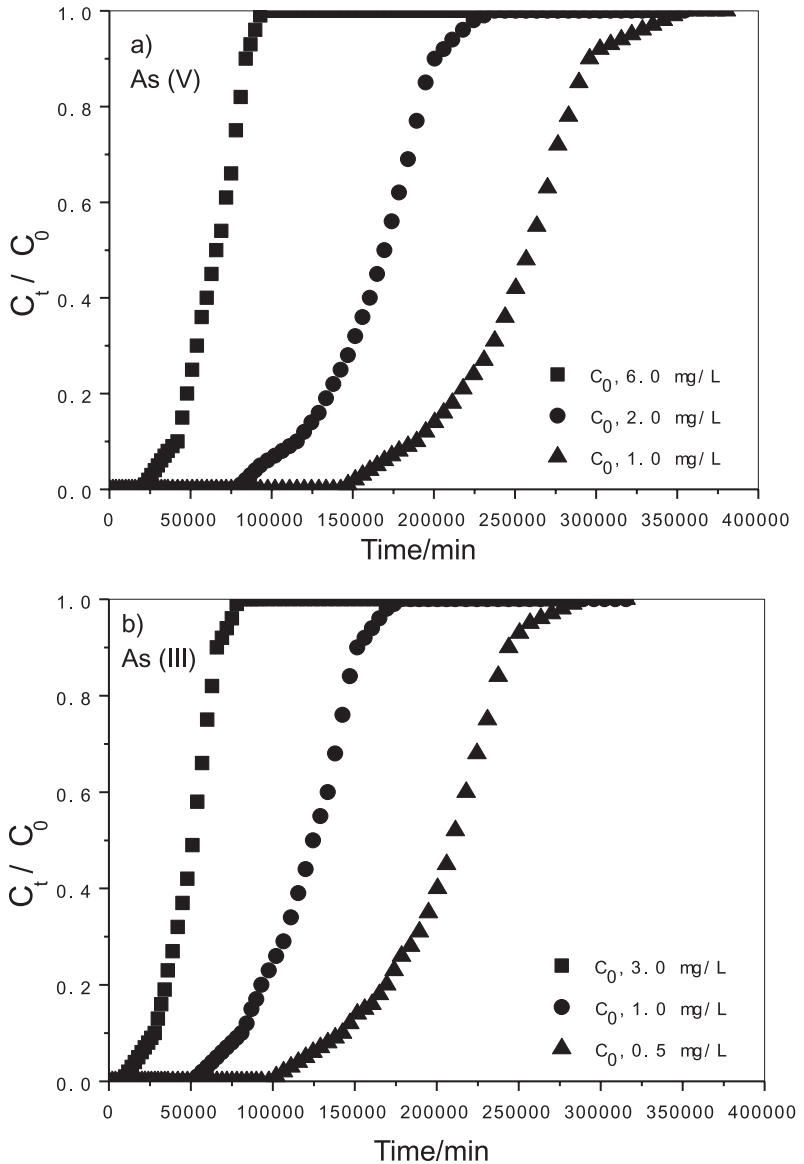

Fig. 4. Effect of initial concentration on the breakthrough curve of arsenic adsorption on OSGs. a) As(V); b) As(III).

(Bed height $32 \mathrm{~cm}$; flow rate $1.36 \mathrm{ml} / \mathrm{min}$.) with the increase of initial arsenic concentration. OSGs reach saturation earlier at higher initial concentration, which leads to the reduction of the breakthrough time. In contrast, decreased initial arsenic concentrations delay the breakthrough point, since the lower concentration gradient caused slower transport velocity and longer contact time.

\section{Effect of Flow Rate}

The effect of flow rate on the breakthrough curves of fixed-bed column adsorption was investigated at a fixed bed height of $32 \mathrm{~cm}$ and initial arsenic concentration of $2.0 \mathrm{mg} / \mathrm{l}$ (Fig. 5). In a fixed-bed column with constant bed height, the breakthrough time is prolonged with the decreased flow rate, indicating a longer column life with longer contact time. The OSG column quickly reaches its maximum capacity at higher flow rate because of more arsenic ions being exchanged with functional group sites in shorter time. The flow rate also influences the $\mathrm{As}(\mathrm{V})$ or As(III) adsorption capacity. When the flow rate increases from 0.91 to $2.72 \mathrm{ml} / \mathrm{min}$, the corresponding breakthrough adsorption capacity decreases from 0.88 to $0.54 \mathrm{mg} / \mathrm{g}$ for $\mathrm{As}(\mathrm{V})$ and from 0.68 to $0.31 \mathrm{mg} / \mathrm{g}$ for $\mathrm{As}(\mathrm{III})$. The probable reason maybe that the contact time of $\mathrm{As}(\mathrm{V})$ or As(III) with OSGs is too short at a higher flow rate,
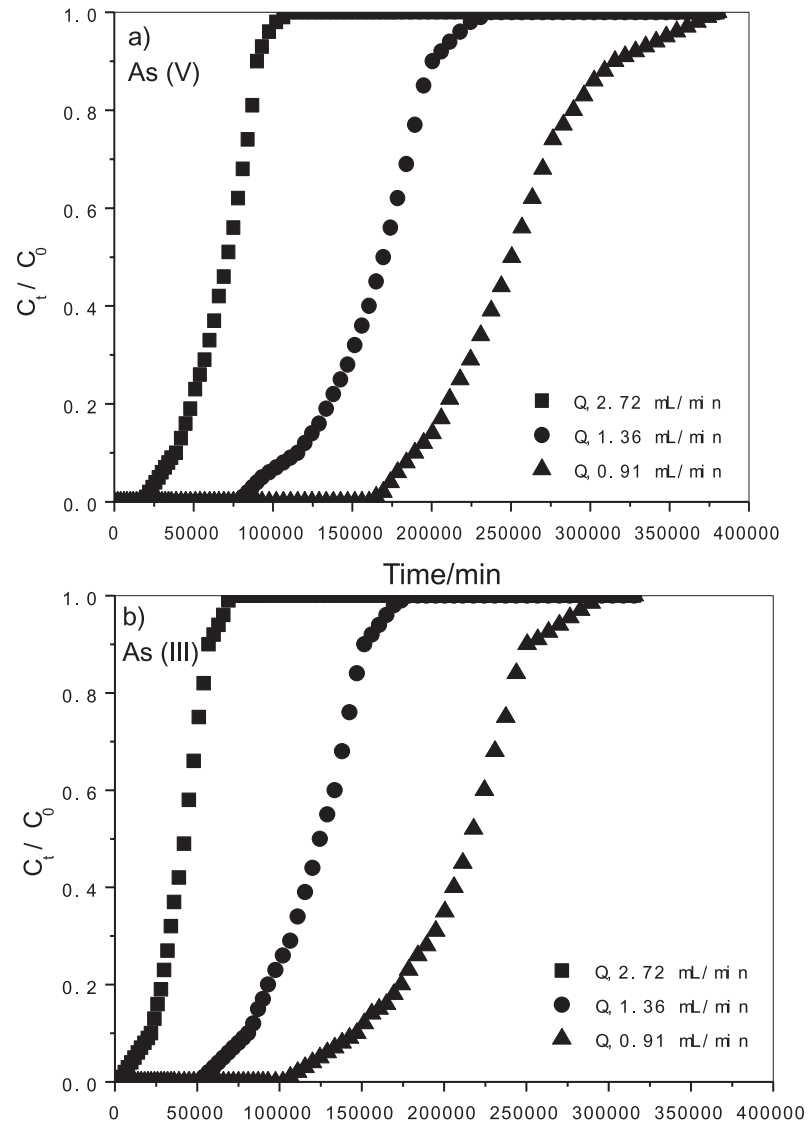

Time/min

Fig. 5. Effect of flow rate on the breakthrough curve of arsenic adsorption on OSGs. a) As(V); b) As(III).

(Initial arsenic concentration $2.0 \mathrm{mg} / \mathrm{L}$; bed height $32 \mathrm{~cm}$.) 
resulting in a reduction in removal efficiency. However, this decrease is not very significant, suggesting that the adsorption of $\mathrm{As}(\mathrm{V})$ or $\mathrm{As}(\mathrm{III})$ on the fixed-bed column is a rapid process.

It also is observed in Fig. 5 that the shape of breakthrough curves are steeper at a higher flow rate, implying higher intra-particle diffusion effect and a narrow mass transfer zone. The flatter breakthrough curves are observed for lower flow rate, which indicate a more prominent effect of film transfer resistance, larger mass transfer zone, and longer service time for the column at longer contact time.

\section{Adsorption Modeling for Fixed Bed Column Studies}

The fixed-bed column design is needed for the prediction of breakthrough curves and the adsorption capacities under different operating conditions. Several theoretical models have been used to describe the breakthrough behavior in continuous adsorption.

\section{Thomas Model}

The Thomas model features non-axial dispersions and a rate-driving force that follows pseudo second-order reversible reaction kinetics. The linearized equation of the Thomas model can be expressed as follows [27]:

$$
\ln \left(\frac{C_{0}}{C_{t}}-1\right)=\frac{k_{T h} q_{\max } M}{v}-\frac{k_{T h} C_{0} V_{\text {eff }}}{v}
$$

...where $k_{T h}$ is the Thomas rate constant $(\mathrm{L} /(\mathrm{mg} \mathrm{min})$, $q_{\max }$ is maximum metal uptake per gram of the adsorbent $(\mathrm{mg} / \mathrm{g})$, and $V_{\text {eff }}$ is effluent volume $(\mathrm{mL})$. The kinetic coefficient, $k_{T h}$, and the adsorption capacity of the column,

Table 1. Thomas model parameters.

\begin{tabular}{|c|c|c|c|c|c|c|}
\hline & $\begin{array}{c}v \\
(\mathrm{ml} / \mathrm{min})\end{array}$ & $\begin{array}{l}M \\
(\mathrm{~g})\end{array}$ & $\begin{array}{c}C_{0} \\
(\mathrm{mg} / \mathrm{l})\end{array}$ & $\begin{array}{c}K_{T h}(1 / \\
(\mathrm{mg} \min ) \\
* 10^{3}\end{array}$ & $\begin{array}{c}q_{\max } \\
(\mathrm{mg} / \mathrm{g})\end{array}$ & $R^{2}$ \\
\hline \multirow{6}{*}{$\mathrm{As}(\mathrm{V})$} & 1.36 & 353 & 1.0 & 53.5 & 0.79 & 0.9728 \\
\hline & 1.36 & 353 & 2.0 & 37.8 & 1.09 & 0.9714 \\
\hline & 1.36 & 353 & 6.0 & 25.7 & 2.10 & 0.9838 \\
\hline & 0.91 & 353 & 2.0 & 32.6 & 1.42 & 0.9585 \\
\hline & 1.36 & 353 & 2.0 & 37.8 & 1.09 & 0.9714 \\
\hline & 2.72 & 353 & 2.0 & 60.7 & 1.01 & 0.9737 \\
\hline \multirow{6}{*}{$\mathrm{As}(\mathrm{III})$} & 1.36 & 353 & 0.5 & 103.7 & 0.39 & 0.9737 \\
\hline & 1.36 & 353 & 1.0 & 88.0 & 0.42 & 0.9770 \\
\hline & 1.36 & 353 & 3.0 & 55.3 & 1.43 & 0.9702 \\
\hline & 0.91 & 353 & 2.0 & 26.5 & 1.08 & 0.9719 \\
\hline & 1.36 & 353 & 2.0 & 44.0 & 0.91 & 0.9770 \\
\hline & 2.72 & 353 & 2.0 & 79.7 & 0.63 & 0.9853 \\
\hline
\end{tabular}
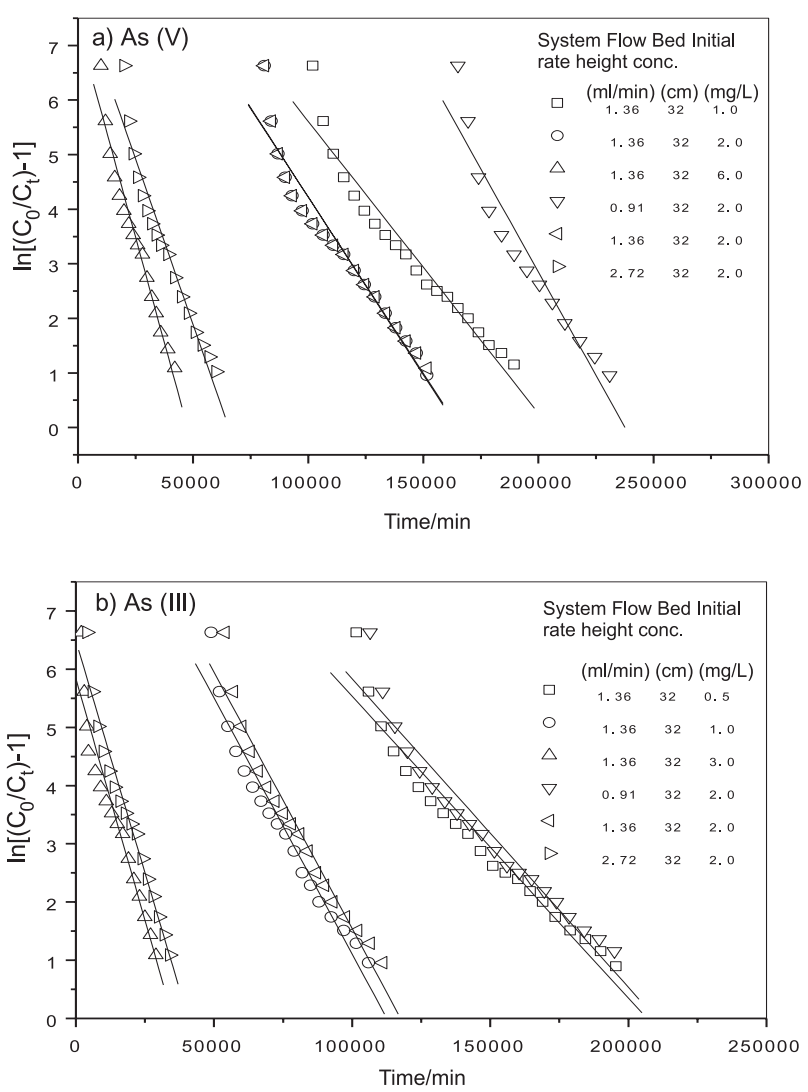

Fig. 6. Thomas model plots. a) As(V); b) As(III).

$q_{\max }$, are determined from the plot of $\ln \left[\left(C_{\delta} / C_{\ell}\right)-1\right]$ against $V_{\text {eff }}$ at a given flow rate. Fig. 6 represents the Thomas model and Table 1 shows the model parameters along with the correlation coefficients. The Thomas model assumes that the external and internal diffusion is not the limiting step and the Langmuir isotherm is valid. But the adsorption is generally controlled by the inter-phase mass transfer and also the existence of an axial dispersion. From Table 1 it is clear that both in $\mathrm{As}(\mathrm{V})$ and $\mathrm{As}(\mathrm{III})$ columns, the rate constant, $k_{T h}$, increases with the increase in flow rate but decreases with increase in initial arsenic ion concentration. But as the maximum adsorption capacity, $q_{\max }$ increases with initial arsenic ion concentration increases but decreases in flow rate. This is due to the high driving force for adsorption between the arsenic ions on the OSGs and the arsenic ion concentration in the solution, and the result shows better column performance. The $R^{2}$ values show that the Thomas model fits well for both $\mathrm{As}(\mathrm{V})$ and $\mathrm{As}(\mathrm{III})$ columns (Table 1).

\section{Adams-Bohart Model}

The Adams-Bohart model is frequently selected for the delineation of fixed-bed column breakthrough for the initial state of the operation [28]. The Adams-Bohart model is as follows:

$$
\ln \left(\frac{C_{t}}{C_{0}}\right)=k_{A B} C_{0} t-\frac{k_{A B} N_{0} Z}{v}
$$



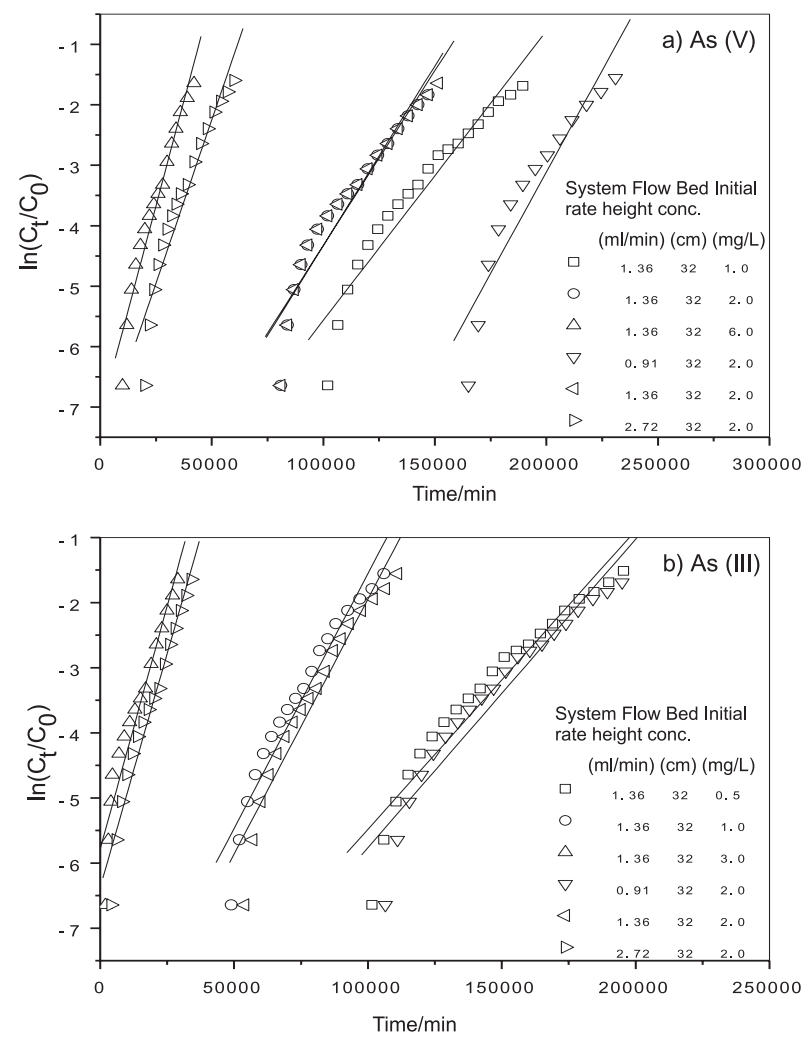

Fig. 7. Adams-Bohart model plots. a) As(V); b) As(III).

...where $k_{A B}$ is the kinetic constant for the Adams-Bohart model $(\mathrm{l} /(\mathrm{mg} \mathrm{min}))$, and $N_{0}$ and $Z$ are the saturation concentration $(\mathrm{mg} / \mathrm{l})$ and bed height of column $(\mathrm{cm})$, respectively. Fig. 7 represents the Adams-Bohart model curve for different initial concentrations of arsenic ions and flow rate. Table 2 shows the parameters, $k_{A B}$ and $N_{0}$, along with the correlation coefficients. It is clear from the table

Table 2. Adams-Bohart model parameters.

\begin{tabular}{|c|c|c|c|c|c|c|}
\hline & $\begin{array}{c}v \\
(\mathrm{ml} / \mathrm{min})\end{array}$ & $\begin{array}{c}Z \\
(\mathrm{~cm})\end{array}$ & $\begin{array}{c}C_{0} \\
(\mathrm{mg} / \mathrm{L})\end{array}$ & $\begin{array}{c}k_{A B} \\
(1 /(m g \text { min })) \\
* 10^{3}\end{array}$ & $\begin{array}{c}N_{0} \\
(\mathrm{mg} / \mathrm{l})\end{array}$ & $\mathrm{R}^{2}$ \\
\hline \multirow{6}{*}{$\begin{array}{l}\text { As } \\
\text { (V) }\end{array}$} & 1.36 & 32 & 1.0 & 47.9 & 9.19 & 0.9620 \\
\hline & 1.36 & 32 & 2.0 & 29.7 & 14.70 & 0.9568 \\
\hline & 1.36 & 32 & 6.0 & 23.1 & 16.14 & 0.9766 \\
\hline & 0.91 & 32 & 2.0 & 23.6 & 19.94 & 0.9433 \\
\hline & 1.36 & 32 & 2.0 & 29.7 & 14.70 & 0.9568 \\
\hline & 2.72 & 32 & 2.0 & 54.0 & 12.05 & 0.9624 \\
\hline \multirow{6}{*}{$\begin{array}{l}\text { As } \\
\text { (III) }\end{array}$} & 1.36 & 32 & 0.5 & 91.8 & 4.66 & 0.9614 \\
\hline & 1.36 & 32 & 1.0 & 78.3 & 4.94 & 0.9660 \\
\hline & 1.36 & 32 & 3.0 & 49.7 & 5.09 & 0.9617 \\
\hline & 0.91 & 32 & 2.0 & 23.7 & 12.60 & 0.9607 \\
\hline & 1.36 & 32 & 2.0 & 39.2 & 10.61 & 0.9660 \\
\hline & 2.72 & 32 & 2.0 & 71.9 & 7.53 & 0.9797 \\
\hline
\end{tabular}

that the kinetic constant, $K_{A B}$, and saturation concentration, $N_{0}$, depend on the initial concentration and flow rate. An increase in the values of $K_{A B}$ are observed with the increase in flow rate for both $\mathrm{As}(\mathrm{V})$ and $\mathrm{As}(\mathrm{III})$ columns (Table 2). Meanwhile, the value of $N_{0}$ increased with initial concentration for both $\mathrm{As}(\mathrm{V})$ and $\mathrm{As}(\mathrm{III})$ columns. When the initial concentration increased, the bed adsorbent in the column achieved comparative exhaustion as the metal ions loading had been higher. These findings show that the sorption kinetic is contributed by the physical mass transfer of the column system. Hence, it indicated that the overall system kinetics are controlled by the external mass transfer in the initial part of the adsorption process within the column [28].

\section{Yoon-Nelson Model}

The Yoon-Nelson model [29] is based on the hypothesis that the probability of adsorption decrease rate of each adsorbate molecule is linearly related to the probability of both adsorbate adsorption and adsorbate breakthrough on the adsorbent. This model is less complicated and easier to apply to describe the practical industrial adsorption process.

The linearized Yoon-Nelson model is given as:

$$
\ln \left(\frac{C_{t}}{C_{0}-C_{t}}\right)=k_{Y N} t-\tau k_{Y N}
$$

... where $k_{Y N}$ is the Yoon-Nelson rate constant $\left(\mathrm{min}^{-1}\right)$ and $\tau$ is the breakthrough time required for $50 \%$ adsorbate
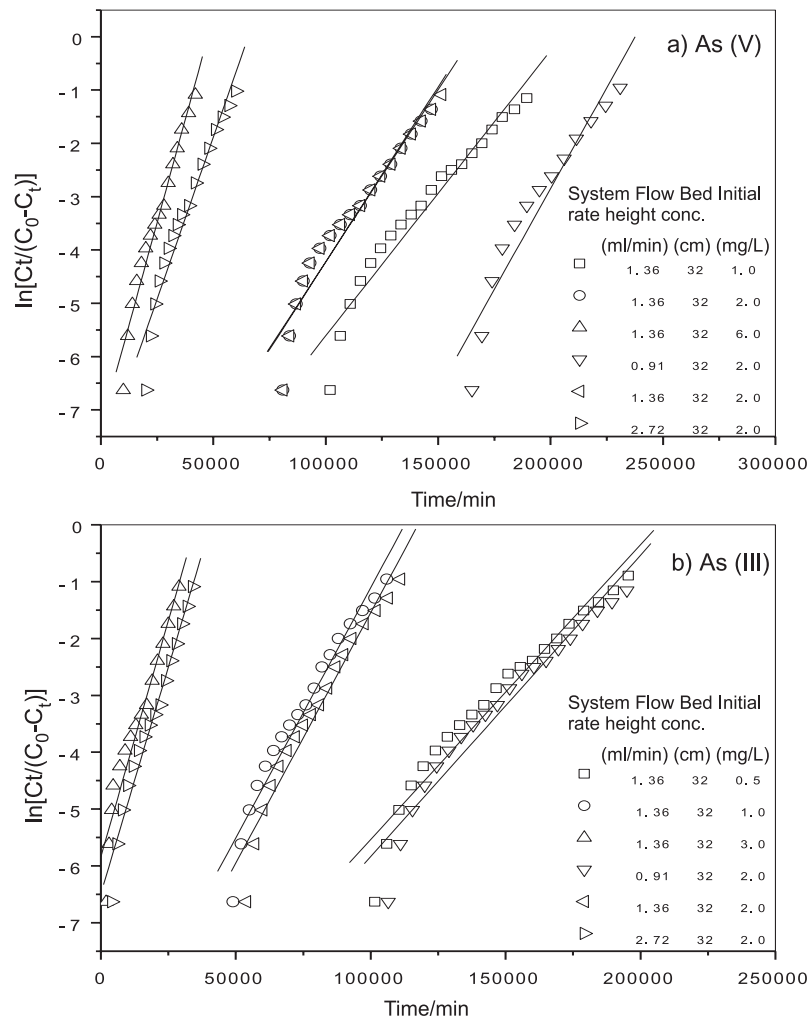

Fig. 8. Yoon-Nelson model plots. a) As(V); b) As(III). 
Table 3. Yoon-Nelson model parameters.

\begin{tabular}{|c|c|c|c|c|c|c|c|}
\hline & $\begin{array}{c}v \\
(\mathrm{ml} / \mathrm{min})\end{array}$ & $\begin{array}{c}Z \\
(\mathrm{~cm})\end{array}$ & $\begin{array}{c}C_{0} \\
(\mathrm{mg} / \mathrm{l})\end{array}$ & $\begin{array}{c}k_{Y N} \\
\left(\min ^{-1}\right) * 10^{3}\end{array}$ & $\begin{array}{c}\tau_{\text {theo }} \\
(\min ) * 10^{-3}\end{array}$ & $\begin{array}{c}\tau_{\exp } \\
(\min ) * 10^{-3}\end{array}$ & $\mathrm{R}^{2}$ \\
\hline \multirow{6}{*}{$\operatorname{As}(\mathrm{V})$} & 1.36 & 32 & 1.0 & 53.5 & 205 & 210 & 0.9728 \\
\hline & 1.36 & 32 & 2.0 & 75.7 & 143 & 169 & 0.9666 \\
\hline & 1.36 & 32 & 6.0 & 154.2 & 48 & 51 & 0.9838 \\
\hline & 0.91 & 32 & 2.0 & 65.7 & 270 & 250 & 0.9585 \\
\hline & 1.36 & 32 & 2.0 & 75.7 & 143 & 169 & 0.9666 \\
\hline & 2.72 & 32 & 2.0 & 121.5 & 66 & 70 & 0.9737 \\
\hline \multirow{6}{*}{$\mathrm{As}(\mathrm{III})$} & 1.36 & 32 & 0.5 & 51.9 & 206 & 209 & 0.9737 \\
\hline & 1.36 & 32 & 1.0 & 88.0 & 113 & 119 & 0.9770 \\
\hline & 1.36 & 32 & 3.0 & 166.0 & 35 & 37 & 0.9702 \\
\hline & 0.91 & 32 & 2.0 & 53.0 & 210 & 211 & 0.9719 \\
\hline & 1.36 & 32 & 2.0 & 88.0 & 118 & 124 & 0.9770 \\
\hline & 2.72 & 32 & 2.0 & 159.5 & 41 & 42 & 0.9853 \\
\hline
\end{tabular}

breakthrough (min). The values of $k_{Y N}$ and $\tau$ can be determined by the linear plot of $\ln \left(\frac{C_{t}}{C_{0}-C_{t}}\right)$ against $t$.

The statistical parameters of Yoon-Nelson are calculated and given in Fig. 8 and Table 3 according to Eq. (4). $k_{Y N}$ increases and $\tau$ decreases with increases of both initial arsenic concentration and flow rate. From the statistical parameters indicated in Table 3, the theoretical breakthrough curves are close to the experimental breakthrough curves, which indicates that Yoon-Nelson fits well with the experimental data for arsenic adsorption on the OSGs fixed-bed column.

Overall, spent grain is an environmentally friendly potential biosorbent for heavy metals. This work examined the efficiency of this sorbent in the removal of $\mathrm{As}(\mathrm{V})$ and As(III) ions from an aqueous environment. The results indicated that initial concentration and flow rate affect the biosorption process. The Thomas, Adam-Bohart, and Yoon-Nelson models were successfully used to predict the breakthrough curves, indicating that they were very suitable for designing OSG columns. The results showed that the modified spent grains have an excellent adsorption capacity for the removal of $\mathrm{As}(\mathrm{V})$ and $\mathrm{As}(\mathrm{III})$ ions.

\section{Conclusions}

We studied the biosorption of $\mathrm{As}(\mathrm{V})$ and $\mathrm{As}(\mathrm{III})$ ions onto the organic modified spent grains (OSGs) fixedbed column. The OSGs efficiently removed As(V) and $\mathrm{As}(\mathrm{III})$ ions in fixed bed column. The uptake of $\mathrm{As}(\mathrm{V})$ and As(III) ions through a fixed-bed column was dependent on the influent concentration and flow rate. The maximum adsorption capacity was at $6.0 \mathrm{mg} / \mathrm{l}$ for $\mathrm{As}(\mathrm{V})$ and $3.0 \mathrm{mg} / \mathrm{l}$ for $\mathrm{As}(\mathrm{III})$ influent concentration and $1.36 \mathrm{ml} / \mathrm{min}$ flow rate. The Thomas, Adams-Bohart, and
Yoon-Nelson models were successfully used to predict the breakthrough curves, indicating that they were very suitable for OSG column design. It is considered to be the cheapest treatment method for removing $\mathrm{As}(\mathrm{V})$ and As(III) ions from industrial effluent.

\section{Acknowledgements}

The authors gratefully acknowledge financial support from the National Natural Science Fund of China (51164014, 51568023). Additionally, the authors would like to express their sincere appreciation to the anonymous reviewers for their helpful comments and suggestions.

\section{References}

1. QIN C., LIU L., HAN Y., CHEN C., LAN Y. Mesoporous Magnetic Ferrum-Yttrium Binary Oxide: a Novel Adsorbent for Efficient Arsenic Removal from Aqueous Solution. Water, Air, \& Soil Pollution 227, 337, 2016.

2. JIANG B., HU P., ZHENG X., ZHENG J., TAN M., WU M., XUE Q. Rapid oxidation and immobilization of arsenic by contact glow discharge plasma in acidic solution. Chemosphere, 125, 220, 2015.

3. BHATTACHARYA P., WELCH A., STOLLENWERK K., MCLAUGHLIN M., BUNDSCHUH J., PANAULLAH G. Arsenic in the environment: biology and chemistry. Sci Total Environ 379, 109, 2007.

4. MOHAN D., PITTMAN C. Arsenic removal from water/ wastewater using adsorbents-A critical review. J Hazard Mat 142, 1, 2007.

5. SHARMA V.K., SOHN M. Aquatic arsenic: toxicity, speciation, transformations, and remediation. A review. Environ Int 35, 743, 2009.

6. DASTGIRI S., MOSAFERI M., FIZ M., OLFATI N., ZOLALI S., POULADI N., AZARFAM P. Arsenic exposure, dermatological lesions, hypertension, and chromosomal 
abnormalities among people in a rural community of Northwest Iran. J Health Popul Nutr 28 (1), 1, 2010.

7. LUTHER S., BORGFELD N., KIM J., PARSONS J.P. Removal of arsenic from aqueous solution: a study of the effects of $\mathrm{pH}$ and interfering ions using iron oxide nanomaterials. Microchem J. 101, 30, 2012.

8. IPCS, Environmental Health Criteria 224, Arsenic and Arsenic Compounds. $2^{\text {nd }}$ ed., World Health Organization, Geneva, Switzerland, 2001.

9. WHO: Guidelines for Drinking-Water Quality, third edition, Recommendations. Geneva: World Health Organization; 2011.

10. Department of Health P. R. of China. Standards for Drinking Water Quality (GB 5749-2006).

11. IMRAN A., ZEID A.O., ABDULRAHMAN A., MOHD A., TABREZ K. Removal of arsenic species from water by batch and column operations on bagasse fly ash. Environ Sci Pollut Res. 21, 3218, 2014. DOI: 10.1007/s11356-013-2235-3.

12. WAN W., PEPPING T.J., BANERJI T., CHAUDHARI S., GIAMMAR D.E. Effects of water chemistry on arsenic removal from drinking water by electrocoagulation. Water Res. 45, 384, 2011.

13. PALLIER V., CATHALIFAUD G.F., SERPAUD B., BOLLINGER J.C. Effect of organic matter on arsenic removal during coagulation/flocculation treatment. J. Colloid Interface Sci. 342, 26, 2010.

14. SONG S., LOPEZ V.A., HERNANDEZ C.D.J., PENG C., MONROY F.M.G. Arsenic removal from high-arsenic water by enhanced coagulation with ferric ions and coarse calcite. Water Res. 40, 364, 2006.

15. ALTUN M., SAHINKAYA E., DURUKAN I., BEKTAS S., KOMNITSAS K. Arsenic removal in a sulfidogenic fixedbed column bioreactor, Journal of Hazardous Materials 269, 31, 2014.

16. MONDAL P., MAJUMDER C.B., MOHANTY B. Treatment of arsenic contaminated water in a batch reactor by using Ralstonia eutropha MTCC 2487 and granular activated carbon. J. Hazard. Mater. 153, 588, 2008.

17. MOLINO A., ERTO A., NATALE F.D., DONATELLI A., IOVANE P., MUSMARRA D. Gasification of Granulated Scrap Tires for the Production of Syngas and a Low-Cost Adsorbent for Cd(II) Removal from Wastewaters. Ind. Eng. Chem. Res., 52, 12154, 2013.
18. CHEN W., PARETTE R., ZOU J., CANNON F.S. DEMPSEY B.A. Arsenic removal by iron-modified activated carbon. Water Res. 41, 1851, 2007. DOI:10.1016/ j.watres.2007.01.052

19. OZER A., OZER D. The adsorption of copper(II) ions on to dehydrated wheat bran (DWB): determination of the equilibrium and thermodynamic parameters. Process Biochem, 39, 2183, 2004.

20. RAJFUR M., KLOS A., WACLAWEK M. Sorption of copper(II) ions in the biomass of alga Spirogyra sp. Bioelectrochemistry, 87, 65, 2012.

21. CHEN Y., CHAI L., NIE J., LUO X., WANG D. The treatment of trace As (III) from water by modified spent grains. DESALIN WATER TREAT. 1, 2015. DOI: 10.1080/ 19443994.2013.855667.

22. LOW K.S., LEE C.K., LIEW S.C. Sorption of cadmium and lead from aqueous solutions by spent grain. Process Biochem. 36, 59, 2000.

23. LOW K.S., LEE C.K., LOW C.H. Sorption of Chromium(VI) by Spent Grains Under Batch Conditions. J. Appl. Polym. Sci., 82, 2128, 2001.

24. CHAI L.Y., CHEN Y.N., YANG Z.H. Kinetics and thermodynamics of arsenate and arsenite biosorption by pretreated spent grains. Water Environ Res. 81 (9), 843, 2009.

25. WENG S.P. Analysis of Fourier Transform Infrared Spectrometry, Chemical Industry Press, Beijing, 2009.

26. BARAL S.S., DAS N., RAMULU T.S., SAHOO S.K., DAS S.N., CHAUDHURY G.R. Removal of Cr (VI) by thermally activated weed Salvinia cucullata in a fixed-bed column. J. Hazard. Mater. 161 (2-3), 1427, 2009.

27. THOMAS H.G. Chromatography: a problem in kinetics, Ann. N.Y. Acad. Sci. 49, 161, 1948.

28. AKSU Z., GÖNEN F. Biosorption of phenol by immobilized activated sludge in acontinuous packed bed: prediction of breakthrough curves, Process Biochem. 39, 599, 2004.

29. PILLI S.R., GOUD V.V., MOHANTY K. Biosorption of $\mathrm{Cr}(\mathrm{VI})$ on immobilized Hydrillaverticillata in a continuous up-flow packed bed: prediction of kinetic parameters and breakthrough curves, Desalination Water Treat. 50 (1-3), 115, 2012. 